\title{
João, o Batista, o maior entre os nascidos de mulheres: uma análise exegética de Mt 11,2-15
}

\author{
Orientador: Waldecir Gonzaga \\ Mestrando: Adalberto do Carmo Telles \\ Área de Concentração: Teologia Bíblica
}

Linha de Pesquisa: Análise e Interpretação de Textos do Antigo e Novo Testamento

Projeto de Pesquisa: Análise retórica bíblica semítica

Esta pesquisa versa sobre "o maior entre os nascidos de mulheres", com base no texto de Mt 11,2-15. Partindo desse princípio, a pesquisa aborda sobre João, o Batista, no testemunho dado por Jesus aos discípulos que estavam à sua volta. É bem verdade que a vida de João, o Batista, é um enigma a ser desvendado, tendo em vista as poucas informações oferecidas a respeito de sua vida, com exceção daquelas que são encontradas em textos do Novo Testamento (Evangelhos e Atos dos Apóstolos) e em textos extrabíblicos. Ao pesquisar essa perícope, encontramos um paralelo em Lc 7,18-28, com suas semelhanças e diferenças, sobre as quais faremos menção aqui em nosso estudo e abordagem. Nesse sentido, esse trabalho faz uma análise do texto base aqui pesquisado, recorrendo ao contexto histórico de Mateus, passando pela comunidade mateana, onde o Evangelho foi desenvolvido e o testemunho de Jesus foi identificado a João, o Batista. Em outro momento, faremos um status quaestionis a respeito do tema "João, o Batista, o maior entre os nascidos de mulheres" em Mt 11,215 com as contribuições necessárias de alguns autores. Por fim, faremos uma exegese da perícope de Mt 11,2-15, seguindo os critérios do Método Histórico-Crítico e da Análise Retórica Bíblica, para alcançarmos o sentido próprio do texto direcionando para a compreensão do tema: "João, o Batista, o maior entre os nascidos de mulheres: Uma análise exegética de Mt 11,2-15”.

Palavras-chave: Jesus. João Batista. Maior e menor. Nascidos de mulheres. Reino dos Céus. 